\title{
Clinical Implication of EGF A61G Polymorphism in the Risk of Non Small Cell Lung Adenocarcinoma Patients: A Case Control Study
}

\author{
Mirza Masroor ${ }^{1 \&}$, Jain Amit ${ }^{1 \&}$, Jamsheed Javid ${ }^{1}$, Rashid Mir ${ }^{2}$, Y Prasant ${ }^{1}$, A \\ Imtiyaz $^{1}$, Z Mariyam ${ }^{1}$, Anant Mohan ${ }^{3}$, PC Ray ${ }^{1}$, Alpana Saxena ${ }^{1 *}$
}

\begin{abstract}
Background: The epidermal growth factor (EGF) plays important roles in non-small cell lung cancer (NSCLC) susceptibility and functional polymorphism in the EGF $(+61 \mathrm{~A} / \mathrm{G})$ gene has been linked to increased risk of NSCLC. This study aimed to evaluate the role of the EGF $+61 \mathrm{~A} / \mathrm{G}$ polymorphism in risk of NSCLC adenocarcinoma (ADC) occurrence and survival in an Indian population. Materials and Methods: This casecontrol study included 100 histopathologically confirmed NSCLC (ADC) patients and 100 healthy controls. EGF (A61G) was genotyped by AS-PCR to elucidate putative associations with clinical outcomes. The association of the polymorphism with the survival of NSCLC patients was estimated by Kaplan-Meier curves. Results: It was found that EGF 61AG heterozygous and GG homozygous genotype is significantly associated with increased risk of NSCLC (ADC) occurrence compared to AA genotype, [OR 2.61 (1.31-5.18) and 3.25 (1.31-8.06), RR 1.51(1.15-2.0) and 1.72 (1.08-2.73) and RD 23.2 (6.90-39.5) and 28.53(7.0-50.1) for heterozygous $A G(p=0.005)$ and homozygous GG ( $(\mathrm{p}=0.009)]$. Patients homozygous for the $\mathrm{G}$ allele exhibited a significantly poor overall survival. The median survival time for patients with EGF 61 AA, AG, and GG genotypes was 10.5, 7.4, and 7.1 months $(\mathrm{p}=0.02)$, respectively. NSCLC (ADC) patients with GG + AG exhibited 7.3 months median survival compared to the AA genotype $(\mathrm{p}=0.009)$. Conclusions: The present study revealed that the EGF A61G genotype may be a novel independent prognostic marker to identify patients at higher risk of occurrence and an unfavourable clinical outcome.
\end{abstract}

Keywords: EGF gene (+61A/G) polymorphism - AS-PCR - NSCLC (ADC) patients

Asian Pac J Cancer Prev, 16 (17), 7529-7534

\section{Introduction}

Non-small cell lung cancer (NSCLC) is the major cancer killer disease worldwide in both males and females accounting for more than 1.2 million deaths each year (Alberg et al., 2005). NSCLC accounts for 75\%-85\% of all histotypes of lung cancer and the overall prognosis of NSCLC patients remains poor with a 5-year survival rate only $14 \%$ while 5 -year survival rate less than $70 \%$ in stage I (Naruke, 1997; Spira et al., 2004). Cancer cells produce high level of their own peptide growth factors and this turn on the cellular proto-oncogenes (Goustin et al., 1986; Aaronson et al., 1991). The epidermal growth factor (EGF) and its receptor (EGFR) play a central role in lung carcinogenesis. The EGF gene is located in chromosome 4q25-27 and its protein may activate DNA synthesis and promotes cellular proliferation by stimulating mitosis (Laurence and Carpenter, et al 1990). EGF mRNA is 4.8- $\mathrm{kb}$ long and their gene is $110-\mathrm{kb}$ long containing 24 exons (Salomon et al., 1995). The interaction between EGF and EGFR may be a risk factor for susceptibility and prognosis in various tumours, such as melanoma, glioblastoma and gastric cancer (Moulder et al., 2001). EGFR signal promote cell proliferation, invasion, metastasis, angiogenesis, and inhibition of apoptosis (Tabernero et al., 2005). The EGF A61G polymorphism is located in the $5^{\prime}$-untranslated region at position 61 and reported to functional influence on increase EGF production. Mononuclear cells from individuals with the AA genotype have been reported to decrease levels of EGF production than cells with GG genotype (Shahbazi et al., 2002). Epidermal growth factor (EGF) is ligand which binds to EGFR receptors and transmits signal further, and it was observed in cancer cells EGFR signalling pathway is often deregulated and which increases proliferation, resistance to apoptosis, metastases and angio-genesis (Ciardiello et al., 2001; 2008; Hynes

${ }^{1}$ Department of Biochemistry, Maulana Azad Medical College and Associated Hospitals, ${ }^{3}$ Department of Pulmonary Medicine and Sleep Disorder, All India Institute of Medical Sciences, New Delhi, India, ${ }^{2}$ Faculty of Applied Medical Sciences, University of Tabuk, Tabuk, Saudi Arabia ¿Equal contributors*For correspondence: biochempublications@gmail.com 
et al., 2005; Gan et al., 2012). EGF ligand binding with its receptor (EGFR) pathway has been demonstrated to play a significant role in transducing growth signals to mitogen-activated protein kinase pathway, as well as the phosphatidylinositol 3-kinase causing NSCLC (Harris et al., 2003; Goto et al., 2005; Araujo et al., 2007). EGF can also disrupt different pathways and contribute to metastasis due to intercalation of integrin $\alpha 6 \beta 4$ with EGFR, which can be important factor for cell migration (Araujo et al., 2007; Teixeira et al., 2008). Shahbazi et al first time found that individuals homozygous for the 61AA genotype produced significantly low EGF level than the homozygous $61 \mathrm{GG}(\mathrm{p}=0.0004)$ or heterozygous $61 \mathrm{AG}$ genotype ( $\mathrm{p}=0.001)$ and suggested that high EGF synthesis is important to melanoma development (Shahbazi et al., 2002; Lim et al., 2005). Many studies have evaluated the role of EGF A61G single nucleotide polymorphism. However, conflicting findings have been reported of EGF A61G polymorphism in lung cancer risk (Kang et al., 2007). In the present study, we hypothesized that EGF (A61G) polymorphism may also be associated with cancer susceptibility, unfavourable clinical behaviour and risk of NSCLC in Indian population.

\section{Materials and Methods}

\section{Cases and controls}

Present study included histo-pathologically confirmed 100 newly diagnosed NSCLC (ADC) patients and 100 healthy controls. $3 \mathrm{ml}$ of peripheral blood sample collected in EDTA vials from each subjects included in the study. This study was approved by the Institutional Ethics Committee of MAMC, New Delhi and written informed consent was obtained from all subjects. Patient follow-up was obtained through the hospital records and follow-up done from May 2013 to May 2015.

\section{DNA extraction and genotype}

Genomic DNA extraction was done by phenol chloroform method from blood samples collected in EDTA vials from NSCLC ADC cases as well as healthy controls. The $+61 \mathrm{~A} / \mathrm{G}$ polymorphism was analysed by allele specific PCR method with EGF +61A Forward 5' GCCCCAATCCAAGGGTTGTA3',EGF+61GForward 5' GCCCCAATCCAAGGGTTGTG 3'and and reverse primer for both alleles is 5' GCCAAGGGAAGCCACAGGAAAG

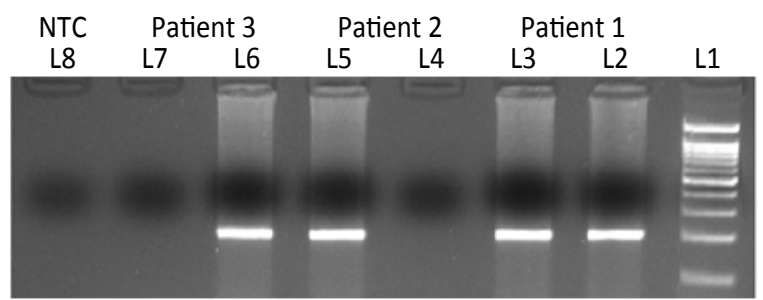

Figure 1. Agarose Gel Picture of EGF+61A/G Amplification. L1:100bp ladder. Patient1; L2 - L3: Both normal (A) and mutant allele (G) amplified: Patients 1 positive for Heterozygous A and G allele. Patient2; L4 - L5: Mutant allele (T) amplified: Patients2 Positive for Homozygous G allele. Patient3; L6 - L7: Normal allele (A) amplified: Patients 1 positive for Homozygous A allele. NTC; L8: Non template control
3' (Kenneth $\mathrm{K}$ et al., 2008). PCR was performed in $25 \mu \mathrm{l}$ reaction volume containing $3 \mu \mathrm{l}$ of $100 \mathrm{ng}$ template DNA, $0.25 \mu \mathrm{l}, 25 \mathrm{pmol}$ each primer $2.5 \mu \mathrm{l}, 10 \mathrm{mM}$ dNTPs, 1.5 $\mu \mathrm{l}$ of $20 \mathrm{mM} \mathrm{MgCl}, 0.3 \mu \mathrm{l}$ of $5 \mathrm{U} / \mu \mathrm{l} \mathrm{Taq}$ polymerase with $2.5 \mu \mathrm{l}$ of $10 \mathrm{X}$ Taq Buffer (Fermantas) and $14.7 \mu \mathrm{l}$ of nuclease-free $\mathrm{ddH}_{2} \mathrm{O}$. The PCR was performed with initial denaturation at $94^{\circ} \mathrm{C}$ for 10 minutes, followed by 40 cycles of denaturation at $95^{\circ} \mathrm{C}$ for 40 seconds, annealing at $58^{\circ} \mathrm{C}$ for 40 seconds, extension at $72^{\circ} \mathrm{C}$ for 40 seconds and the final extension was at $72^{\circ} \mathrm{C}$ for 10 minutes. Amplified 206bp PCR products were separated by electrophoresis on a $2 \%$ agarose gel containing ethidium bromide (Figure 1).

\section{Statistical analysis}

Genotype frequencies between the cases and controls were evaluated using the Chi square test, Hardy-Weinberg equilibrium test used to check the allele frequency and values below 5 were analyzed by Fisher exact test. The associations between A61G genotypes and risk of NSCL cancer (ADC) were estimated by computing the odds ratios (ORs) and risk ratios (RRs) with $95 \%$ confidence intervals (CIs). Kaplan-Meier methods were used to evaluate the relationship between $\mathrm{A} 61 \mathrm{G}$ genotype and

Table 1. Distribution of Selected Characteristics among NSCLC Patients and Healthy Controls

\begin{tabular}{|c|c|c|}
\hline \multirow{2}{*}{$\begin{array}{l}\text { Variables } \\
\text { Total no. }\end{array}$} & \multicolumn{2}{|c|}{ NSCLC patients (\%)Healthy controls (\%) } \\
\hline & 100 & 100 \\
\hline \multicolumn{3}{|l|}{ Gender } \\
\hline Males & 65 & 71 \\
\hline Females & 35 & 29 \\
\hline \multicolumn{3}{|c|}{ Age at diagnosis ( In years) } \\
\hline$<55$ & 43 & 56 \\
\hline$>55$ & 57 & 44 \\
\hline \multirow{2}{*}{ Mean + SD age (years) } & $55.4+12.29$ & $54.25+10.82$ \\
\hline & nge32-89 years) & (range $30-70$ years) \\
\hline \multicolumn{3}{|l|}{ Smoking status } \\
\hline Non smokers & 56 & 55 \\
\hline Smokers & 44 & 45 \\
\hline Current smokers & 25 & 24 \\
\hline Ex-smokers & 19 & 21 \\
\hline \multicolumn{3}{|l|}{ Smoking type } \\
\hline Cigarette & 15 & 18 \\
\hline Bidi & 23 & 16 \\
\hline Cigarette + Bidi & 6 & 11 \\
\hline \multicolumn{3}{|l|}{ Smoking level (pack year) } \\
\hline Mild $(<10)$ & 33 & 23 \\
\hline Moderate $(<40)$ & 11 & 18 \\
\hline Heavy $(>40)$ & 0 & 4 \\
\hline \multicolumn{3}{|l|}{ TNM Stage } \\
\hline Stage III & 25 & \\
\hline Stage IV & 75 & \\
\hline \multicolumn{3}{|l|}{ Distant Metastases } \\
\hline Positive & 75 & \\
\hline Negative & 25 & \\
\hline \multicolumn{3}{|l|}{ Histopathological Grade } \\
\hline Grade 1 & 41 & \\
\hline Grade 2 & 23 & \\
\hline Grade 3 & 36 & \\
\hline \multicolumn{3}{|l|}{ Pleural effusion } \\
\hline Yes & 28 & \\
\hline No & 72 & \\
\hline
\end{tabular}


Table 2. Genotype frequencies of EGF (A61G) among NSCLC cases and controls

\begin{tabular}{lcccccc}
\hline Variables & AA & AG & GG & p value & $\begin{array}{c}\text { A allele } \\
\text { frequency }\end{array}$ & $\begin{array}{c}\text { G allele } \\
\text { frequency }\end{array}$ \\
\hline Patients $(\mathrm{n}=100)$ & $17(17 \%)$ & $63(63 \%)$ & $20(20 \%)$ & 0.008 & 0.45 & 0.55 \\
Controls $(\mathrm{n}=100)$ & $36(36 \%)$ & $51(51 \%)$ & $13(13 \%)$ & & 0.61 & 0.39 \\
\hline
\end{tabular}

Table 3. EGF Genotype Frequencies in Cases \& Controls and Associations with NSCLC Risk

\begin{tabular}{lcccccc}
\hline EGF (A61G) Genotype & Control $(\mathrm{n}=100)$ & Cases $(\mathrm{n}=100)$ & $\mathrm{OR}(95 \% \mathrm{CI})$ & $\mathrm{RR}(95 \% \mathrm{CI})$ & $\mathrm{RD}(95 \% \mathrm{CI})$ & $\mathrm{P}$ value \\
\hline AA & $36(36 \%)$ & $17(17 \%)$ & $\operatorname{Ref}(1)$ & $\operatorname{Ref}(1)$ & & \\
AG & $51(51 \%)$ & $63(63 \%)$ & $2.61(1.31-5.18)$ & $1.51(1.15-2.0)$ & $23.19(6.90-39.47)$ & 0.005 \\
GG & $13(13 \%)$ & $20(20 \%)$ & $3.25(1.31-8.06)$ & $1.72(1.08-2.73)$ & $28.53(7.0-50.05)$ & 0.009 \\
AG+GG & $64(64 \%)$ & $83(83 \%)$ & $2.74(1.41-5.32)$ & $1.56(1.20-2.02)$ & $24.39(8.68-40.09)$ & 0.002 \\
\hline
\end{tabular}

OR odd ratio, $\mathrm{RR}$ risk ratio, $\mathrm{RD}$ risk differences

Table 4. Association between the EGF (A61G) Genotype and Clinico-pathological Characteristics in Cases

\begin{tabular}{|c|c|c|c|c|c|}
\hline Variables & & Group I & Group II & OR & RR \\
\hline \multirow[t]{4}{*}{ Gender } & & Male & Female & & \\
\hline & $\mathrm{AA}$ & 9 & 8 & $\operatorname{Ref}(1)$ & $\operatorname{Ref}(1)$ \\
\hline & $\mathrm{AG}$ & 41 & 22 & $0.60(0.20-1.78)$ & $0.81(0.50-1.31)$ \\
\hline & GG & 15 & 5 & $0.37(0.09-1.50)$ & $0.70(0.42-1.18)$ \\
\hline \multirow[t]{4}{*}{ Age (in years) } & & $<55$ & $>55$ & & \\
\hline & AA & 8 & 9 & $\operatorname{Ref}(1)$ & $\operatorname{Ref}(1)$ \\
\hline & $\mathrm{AG}$ & 28 & 35 & $1.11(0.37-3.25)$ & $1.05(0.59-1.88)$ \\
\hline & GG & 7 & 13 & $1.65(0.43-6.62)$ & $1.34(0.61-2.93)$ \\
\hline \multirow[t]{4}{*}{ Smoking behaviour } & & Non-smokers & Smokers & & \\
\hline & AA & 14 & 3 & $\operatorname{Ref}(1)$ & $\operatorname{Ref}(1)$ \\
\hline & $\mathrm{AG}$ & 31 & 32 & $4.81(1.25-18.43)$ & $1.67(1.19-2.33)$ \\
\hline & GG & 11 & 9 & $3.81(0.82-17.58)$ & $1.49(0.95-2.35)$ \\
\hline \multirow[t]{4}{*}{ Smoking status } & & Current Smokers & Ex-smokers & & \\
\hline & AA & 3 & 0 & $\operatorname{Ref}(1)$ & $\operatorname{Ref}(1)$ \\
\hline & $\mathrm{AG}$ & 17 & 15 & $6.20(0.29-129.8)$ & $1.88(1.35-2.60)$ \\
\hline & GG & 5 & 4 & $5.72(0.22-142.7)$ & $1.80(1.00-3.22)$ \\
\hline \multirow[t]{4}{*}{ Smoking type } & & Cigarette & Bidi & & \\
\hline & AA & 0 & 1 & $\operatorname{Ref}(1)$ & $\operatorname{Ref}(1)$ \\
\hline & $\mathrm{AG}$ & 12 & 16 & $0.44(0.01-11.75)$ & - \\
\hline & GG & 3 & 6 & $0.61(0.01-19.60)$ & - \\
\hline \multirow[t]{4}{*}{ Smoking type } & & Cigarette & Cigarette + Bidi & & \\
\hline & AA & 0 & 2 & $\operatorname{Ref}(1)$ & $\operatorname{Ref}(1)$ \\
\hline & $\mathrm{AG}$ & 12 & 4 & $0.07(0.002-1.80)$ & - \\
\hline & GG & 3 & 0 & $0.02(0.0004-1.99)$ & - \\
\hline \multirow[t]{4}{*}{ Smoking type } & & Bidi & Cigarette + Bidi & & \\
\hline & AA & 1 & 2 & $\operatorname{Ref}(1)$ & $\operatorname{Ref}(1)$ \\
\hline & $\mathrm{AG}$ & 16 & 4 & $0.12(0.008-1.75)$ & $0.41(0.08-2.09)$ \\
\hline & GG & 6 & 0 & $0.04(0.001-1.55)$ & $0.33(0.06-1.65)$ \\
\hline \multirow[t]{4}{*}{ Smoking level (pack year) } & & $\operatorname{Mild}(<10)$ & Moderate $(<40)$ & & \\
\hline & AA & 2 & 1 & $\operatorname{Ref}(1)$ & $\operatorname{Ref}(1)$ \\
\hline & $\mathrm{AG}$ & 24 & 8 & $0.66(0.05-8.37)$ & $0.88(0.38-2.02)$ \\
\hline & GG & 7 & 2 & $0.57(0.03-10.08)$ & $0.85(0.35-2.08)$ \\
\hline \multicolumn{6}{|c|}{ TNM Stage, Stage III, Stage IV } \\
\hline & AA & 3 & 14 & $\operatorname{Ref}(1)$ & $\operatorname{Ref}(1)$ \\
\hline & $\mathrm{AG}$ & 18 & 45 & $0.53(0.13-2.09)$ & $0.61(0.20-1.85)$ \\
\hline & GG & 4 & 16 & $0.85(0.16-4.50)$ & $0.88(0.22-3.40)$ \\
\hline \multirow[t]{4}{*}{ Distant Metastases } & & Positive & Negative & & \\
\hline & $\mathrm{AA}$ & 14 & 3 & $\operatorname{Ref}(1)$ & $\operatorname{Ref}(1)$ \\
\hline & $\mathrm{AG}$ & 45 & 18 & $1.86(0.47-7.28)$ & $1.15(0.88-1.51)$ \\
\hline & GG & 16 & 4 & $1.16(0.22-6.13)$ & $1.02(0.75-1.40)$ \\
\hline \multirow[t]{4}{*}{ Pleural Effusion } & & No & Yes & & \\
\hline & AA & 10 & 7 & $\operatorname{Ref}(1)$ & $\operatorname{Ref}(1)$ \\
\hline & $\mathrm{AG}$ & 47 & 16 & $0.48(0.15-1.49)$ & $0.78(0.51-1.20)$ \\
\hline & GG & 15 & 5 & $0.47(0.11-1.93)$ & $0.78(0.48-1.25)$ \\
\hline
\end{tabular}


overall survival of NSCLC patients. All statistical analyses were performed using Graph Pad Prism 6.0 and SPSS 16.0.

\section{Results}

\section{Study population}

All demographic features of the subjects are depicted in table-1. In brief, total of 100 Non-small cell lung ADC patients and same number of healthy control were analyzed. Both NSCLC (ADC) cases and controls include $65 \%$ males and $35 \%$ females of age $<55$ group (43\%) and $>55$ group $(57 \%)$ with mean \pm SD in cases of $55.4+12.29$ (range $32-89$ years) and controls of 54.25+10.82 (range $30-70$ years). $75 \%$ patients were in stage IV, and $25 \%$ patients in stage III while $75 \%$ patients had distant metastases. Patients with different pathological grade, grade 1 (well differentiated) includes $41 \%$, grade 2 (moderately differentiated) includes $23 \%$ and grade 3 (Poorly differentiated) includes $36 \%$ cases. We included smoker $44 \%$ as well as non smoker $56 \%$ with different smoking type as cigarette, bidi, and both, $15 \%$ cases smoked cigarette, $23 \%$ cases smoked bidi and $6 \%$ cases smoked both cigarette and bidi.

Genotype $(A 61 G)$ distribution among Cases and Controls

The genotype and allele distributions of A61G in cases and controls are summarized in Table 2 and 5. We found statistically significant difference in genotype distribution of $\mathrm{A} 61 \mathrm{G}$ in cases and healthy controls $(\mathrm{p}=0.0008)$. The frequency of $\mathrm{G}$ allele (fG) was to be higher among NSCLC (ADC) patients (0.55) compared to healthy controls (0.39) and the frequency of A allele (fA) in healthy controls was to be higher (0.61) compared to NSCLC cases (0.45).

\section{EGF (A61G) genotype and NSCLC risk}

Odds ratio and risk ratio with $95 \%$ confidence intervals was calculated for each group to estimate the degree of association between the EGF (A61G) genotypes and risk of NSCLC in patients. Compared to AA genotype, OR 2.61(1.31-5.18) and 3.25(1.31-8.06), RR 1.51(1.15$2.0)$ and 1.72(1.08-2.73) and RD 23.19(6.90-39.47) and 28.53(7.0-50.05) for heterozygous AG $(\mathrm{p}=0.005)$ and homozygous GG $(\mathrm{p}=0.009)$ genotype were estimated. It was found and suggesting that possible dominant effect of EGFA61G polymorphism on NSCLC (ADC) risk in Indian population. It was also observed that smoking behaviour and smoking status with heterozygous AG and homozygous GG had increased risk of NSCLC disease Table 3, 4 .

\section{EGF (A61G) genotype and NSCLC survival analysis}

Survival analysis of 100 NSCLC (ADC) patients, based on genotype distribution was done and it was found that the mean follow-up time of the patients was 8.64 months (median 10.60; range 1- 24.3 months) for the overall survival. NSCLC-related deaths events $86(86 \% \%)$ with mean follow-up time of 7.1 months (median 7.35; range 1-15.8 months) and for the patients
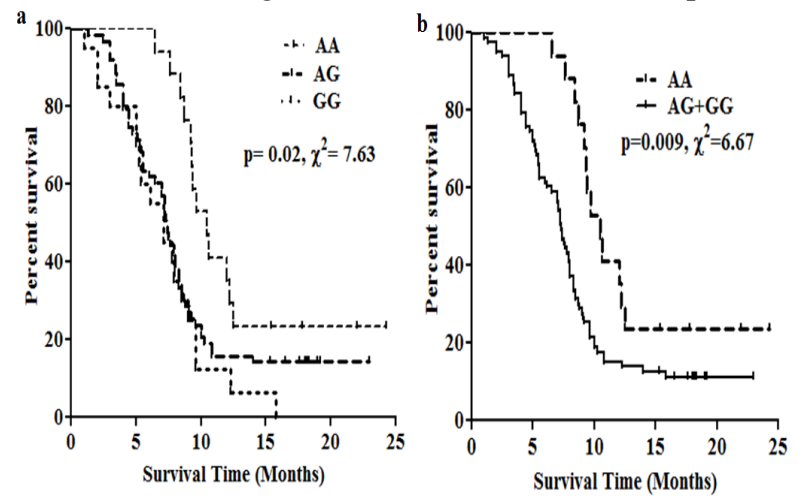

Figure 2. Kaplan-Meier Survival Curves of NSCLC Patients with Respect to EGF (A61G) Polymorphism

Table 5. Association and Stratification Analysis of EGF (A61G) Polymorphism and NSCLC

\begin{tabular}{|c|c|c|c|c|c|c|c|}
\hline Variables & & Total & $\begin{array}{c}\text { AA Genotype } \\
\mathrm{n}(\%)\end{array}$ & $\begin{array}{c}\text { AG Genotype } \\
\mathrm{n}(\%)\end{array}$ & $\begin{array}{c}\text { GG Genotype } \\
\text { n }(\%)\end{array}$ & $\begin{array}{c}\text { A allele } \\
\text { frequency }\end{array}$ & $\begin{array}{l}\text { G allele } \\
\text { frequency }\end{array}$ \\
\hline \multirow[t]{2}{*}{ Gender } & Male & 65 & $9(13.84 \%)$ & $41(63.08 \%)$ & $15(23.08 \%)$ & 0.45 & 0.55 \\
\hline & Female & 35 & $8(22.85 \%)$ & $22(62.86 \%)$ & $5(14.29 \%)$ & 0.54 & 0.46 \\
\hline \multirow[t]{2}{*}{ Age (in years) } & $<55$ & 43 & $8(18.60 \%)$ & $28(65.12 \%)$ & $7(16.28 \%)$ & 0.51 & 0.49 \\
\hline & $>55$ & 57 & $9(15.79 \%)$ & $35(61.40 \%)$ & $13(22.81 \%)$ & 0.41 & 0.59 \\
\hline \multirow[t]{4}{*}{ Smoking status } & Nonsmokers & 56 & $14(25 \%)$ & $31(55.35 \%)$ & $11(19.65 \%)$ & 0.52 & 0.48 \\
\hline & Smokers & 44 & $3(6.81 \%)$ & $32(72.73 \%)$ & $9(20.46 \%)$ & 0.43 & 0.57 \\
\hline & Current Smokers & 25 & $3(12 \%)$ & $17(68 \%)$ & $5(20 \%)$ & 0.46 & 0.54 \\
\hline & Ex-smokers & 19 & $0(0 \%)$ & $15(78.94 \%)$ & $4(21.06 \%)$ & 0.39 & 0.61 \\
\hline \multirow[t]{3}{*}{ Smoking type } & Cigarette & 15 & $0(0 \%)$ & $12(80 \%)$ & $3(20 \%)$ & 0.4 & 0.6 \\
\hline & Bidi & 23 & $1(4.35 \%)$ & $16(69.56 \%)$ & $6(26.09 \%)$ & 0.39 & 0.61 \\
\hline & Cigarette+ Bidi & 6 & $2(33.4 \%)$ & $4(66.7 \%)$ & $0(0 \%)$ & 0.66 & 0.34 \\
\hline \multirow[t]{2}{*}{ Smoking level (pack year) } & $\operatorname{Mild}(<10)$ & 33 & $2(6.06 \%)$ & $24(72.72 \%)$ & $7(21.22 \%)$ & 0.42 & 0.57 \\
\hline & Moderate $(<40)$ & 11 & $1(9.09 \%)$ & $8(72.73 \%)$ & $2(18.18 \%)$ & 0.45 & 0.55 \\
\hline TNM Stage & 25 & $3(12 \%)$ & $18(72 \%)$ & $4(16 \%)$ & 0.48 & 0.52 & \\
\hline IV & 75 & $14(18.67 \%)$ & $45(60 \%)$ & $16(21.33)$ & 0.49 & 0.51 & \\
\hline \multirow[t]{2}{*}{ Distant Metastases } & Positive & 75 & $14(18.67 \%)$ & $45(60 \%)$ & $16(21.33 \%)$ & 0.49 & 0.51 \\
\hline & Negative & 25 & $3(12 \%)$ & $18(72 \%)$ & $4(16 \%)$ & 0.48 & 0.52 \\
\hline \multirow[t]{3}{*}{ Histopathological Grade } & Grade I & 41 & $2(4.87 \%)$ & $35(85.37 \%)$ & $4(9.76 \%)$ & 0.47 & 0.53 \\
\hline & Grade II & 23 & $2(8.69 \%)$ & $10(43.48 \%)$ & $11(47.83 \%)$ & 0.3 & 0.7 \\
\hline & Grade III & 36 & $13(36.12 \%)$ & $18(50 \%)$ & $5(13.88 \%)$ & 0.61 & 0.39 \\
\hline \multirow[t]{2}{*}{ Pleural effusion } & No & 72 & $10(13.88 \%)$ & $47(65.28 \%)$ & $15(20.84 \%)$ & 0.46 & 0.54 \\
\hline & Yes & 28 & $7(25 \%)$ & $16(57.14 \%)$ & $5(17.86 \%)$ & 0.53 & 0.47 \\
\hline
\end{tabular}


Clinical Implications of the EGF A61G Polymorphism in NSCLC Adenocarcinoma Patients: a Case-Control Study

who survived, the follow-up time was approximately 18.12 months (median 18.1; range 9.1-24.3 months). Patients homozygous for $\mathrm{G}$ allele exhibited a significant poor overall survival $(\mathrm{p}=0.02)$. Median survival time for patients with EGF $61 \mathrm{AA}, \mathrm{AG}, \mathrm{GG}+\mathrm{AG}$ and $\mathrm{GG}$ genotype was $10.5,7.4,7.3$ and 7.1 months, respectively. Significant poor overall survival was observed in NSCLC (ADC) patients presented with EGF 61 GG genotype (Figure2a, b).

\section{Discussion}

Presence of the EGF $+61 \mathrm{G}$ allele is a key point in the steps towards carcinogenesis by increasing serum EGF and stimulating proliferation, angiogenesis and metastasis (Zhang et al., 2010). Interaction between serum EGF and its receptor (EGFR) is very important in NSCLC framework. EGF interaction with its receptor (EGFR) has been demonstrated to play a critical role in lung cancer carcinogenesis and tumour aggressiveness, mainly in NSCLC patients. The EGF/EGFR pathway transduces growth signals to mitogen-activated protein kinase pathway, phosphatidylinositol 3-kinase and other downstream pathways (Harris et al., 2003; Goto et al., 2005; Araujo et al., 2007; Zhang et al., 2010; HuLieskovan et al., 2011). Costa et al in 2007 showed that the $+61 \mathrm{G}$ allele was associated with a high EGF expression level in vitro (Costa et al., 2007). Wu et al in 2009 found a statistically significant association between EGF +61 $\mathrm{G} / \mathrm{G}$ genotype and the $+61 \mathrm{G}$ allele with risk for colorectal cancer and pancreatic cancer risk development (Wu et al., 2009). Lim and colleagues conducted a study on schizophrenic patients and lung cancer patients in Korean population to analyse the EGF A61G polymorphism and observed an association of the EGF $+61 \mathrm{~A} / \mathrm{G}$ and EGF $+61 \mathrm{G} / \mathrm{G}$ genotypes with lung cancer risk (OR 2.3,95\% CI 1.6082-3.3687) (Lim et al., 2005). Meta-analysis studies also showed that EGF A61G polymorphism is associated with overall cancer risk (Zhang et al., 2010; Li et al., 2012). The present data explored the association of EGF (A61G) polymorphism with risk and unfavourable clinical outcome of non-small cell lung cancer. We also observed a positive association between $\mathrm{EGF}+61 \mathrm{~A} / \mathrm{G}$ polymorphism with NSCLC (ADC) patients. A significant difference was observed in distribution of EGF (A61G) genotype in NSCLC cases and controls. Our study, the first report from Indian population, suggested that homozygous EGF (+61)GG genotype is strongly associated with the risk of developing NSCLC ADC with approximately more than 3 fold increase than homozygous EGF (+61)AA genotype. EGF (+61) GG genotype was also been found to be an independent factor for unfavourable clinical outcome, However patients with GG genotype at higher risk for death than AA genotype of NSCLC patients. Increased risk of NSCLC (ADC) is also associated smoking behaviour and smoking status. EGF A61G polymorphism is also associated with other cancers, Ying Piao et al suggested that G allele and GG genotype of EGF A+61G (rs4444903) polymorphism has correlations with esophageal and colorectal cancer (Ying et al., 2013). In a study, Vauleon et al (Vauleon et al., 2007) showed that the $+61 \mathrm{~A} / \mathrm{G}$ is functional polymorphism and the promoter with $\mathrm{G}$ allele had $40 \%$ more active than the A variant $(\mathrm{p}<0.001)$. Costa et al. (Costa et al., 2007) also found that the $G$ allele conferred higher risk for gliomas, glioblastomas, and oligodendrogliomas and it was significantly associated with increased risk for gliomas. The prevalence of the $G / G$ genotype was significantly higher in melanoma patients, the $\mathrm{G}$ allele was present in nearly $66 \%$ of patients with malignant melanoma (odds ratio 4.9 [95\% CI 2.3-10.2]; $\mathrm{p}<0.0001$ ) (Shahbazi et al., 2002). Ichiro O et al in 2007 found a significant association between the highexpression homozygous $\mathrm{G} / \mathrm{G}$ genotype of the EGF gene and shorter disease-free period and Malignant Melanoma specific survival compared to A/G and A/A carriers (Ichiro O et al., 2007).

In conclusion, the present study we showed first time that EGF +61AG heterozygous and GG homozygous genotype are associated with reduced overall survival and risk of developing NSCLC (ADC) in the Indian population. EGF represents a novel prognostic marker to identify patients at higher risk for unfavourable clinical outcome. In addition, EGF (A61G) genotyping can be useful to decide specific EGF targeted therapy as well as in the management of NSCLC (ADC) patients.

\section{Acknowledgements}

The authors thank all the study subjects and All India Institute of Medical Sciences, New Delhi, for assistance in recruiting the subjects.

\section{References}

Aaronson SA (1991). Growth factors and cancer. Science 1991. 254, 1146-53.

Alberg AJ, Brock MV, Samet JM (2005). Epidemiology of lung cancer: Looking to the future. J Clin Oncol, 23, 3175-85.

Araujo A, Ribeiro R, Azevedo I, et al (2007). Genetic polymorphisms of the epidermal growth factor and related receptor in non-small cell lung cancer-a review of the literature. Oncologist, 12, 201-10.

Carpenter G, Cohen S (1990). Epidermal growth factor. J Biol Chem, 265, 7709-12.

Ciardiello F, Tortoa G (2008). EGFR antagonist in cancer treatment. $N$ Engl J Med, 358, 1160-74.

Ciardiello F, Tortoa G (2001). A novel approach in the treatment of cancer: targeting the epidermal growth factor receptor. Clin Cancer Res, 7, 2958-70.

Costa BM, Ferreira P, Costa S, et al (2007). Association between functional EGF+61 polymorphism and glioma risk. Clin Cancer Res, 13, 2621-6.

Gan HK, Burgess AW, Clayton AHA, et al (2012). Targeting of a conformationally exposed, tumor-specific epitope of EGFR as a strategy for cancer therapy. Cancer Res, 72, 2924-30.

Goto Y, Ando T, Goto H, et al (2005). No association between EGF gene polymorphism and gastric cancer. Cancer Epidemiol Biomarkers Prev, 14, 2454-6.

Goustin AS, Leof AB, Shipley GD (1986). Growth factors and cancer. Cancer Res, 46, 1015-1029.

Harris R, Chung E, Coffey RJ, et al (2003). EGF receptor ligands. Exp Cell Res, 284, 2-13.

Hu-Lieskovan S, Vallbohmer D, Zhang W, et al (2011). EGF61 polymorphism predicts complete pathologic response to cetuximab-based chemoradiation independent of KRAS 
status in locally advanced rectal cancer patients. Clin Cancer Res, 17, 5161-9.

Hynes NE, Lane HA (2005). ERBB receptors and cancer: the complexity of targeted inhibitors. Nat Rev Cancer, 5, 341-54.

Ichiro Okamoto, Florian Roka, Julia Krogler, et al (2006). The EGF A61G polymorphism is associated with disease-free period and survival in malignant melanoma. Journal of Investigative Dermatology, 126, 2242-6.

Kang H, Choi JE, Lee WK, et al (2007) + +61 A >G polymorphism in the EGF gene does not increase the risk of lung cancer. Respirology, 12, 902-5.

Kenneth K. Tanabe, Antoinette Lemoine, et al (2008). Epidermal growth factor gene functional polymorphism and the risk of hepatocellular carcinoma in patients with cirrhosis, JAMA, 299, 53-60.

Laurence DJ, Gusterson BA (1990). The epidermal growth factor: A review of structural and functional relationships in the normal organism and in cancer cells. Tumor Biol, 11, 229-61.

Lim Y, Kim JW, Song JY, et al (2005). Epidermal growth factor gene polymorphism is different between schizophrenia and lung cancer patients in Korean population. Neurosci Lett, 374, 157-60.

Li T, Ke-Wei Ren, and Peng-Fei Liu (2012). Meta-analysis of epidermal growth factor polymorphisms and cancer risk: involving 9,779 cases and 15,932 controls. DNA Cell Biol.

Moulder SL, Yakes FM, Muthuswamy SK, et al (2001). Epidermal growth factor receptor (HER1) tyrosine kinase inhibitor ZD1839 (Iressa) inhibits HER2/ neu (erbB2) overexpressing breast cancer cells in vitro and in vivo. Cancer Res, 61, 8887-95.

Naruke T, Tsuchiya R, Kondo H, et al (1997). Implications of staging in lung cancer. Chest, 112, 242-8.

Salomon DS, Brandt R, Ciardello F, et al (1995). Epidermal growth factor-related peptides and their receptors in human malignancies. Crit Rev Oncol Hematol, 19, 183-232.

Shahbazi M, Pravica V, Nasreen N, et al (2002). Association between functional polymorphism in EGF gene and malignant melanoma. Lancet, 359, 397-401.

Spira A, Ettinger DS (2004). Multidisciplinary management of lung cancer. N Engl J Med, 350, 379-92.

Tabernero J, Macarulla T, Ramos FJ, et al (2005). Novel targeted therapies in the treatment of gastric and esophageal cancer. Ann Oncol, 16, 1740-8.

Teixeira A, et al (2008). Genetic polymorphism in EGF is associated with prostate cancer aggressiveness and progression-free interval in androgen blockade-treated patients. Clin Cancer Res, 14, 3367-71.

Vauleon E, Auger N, Benouaich-Amiel A, JY, Thillet J, Sanson $\mathrm{M}$ : The $61 \mathrm{~A} / \mathrm{G}$ EGF polymorphism is functional but is neither a prognostic marker nor a risk factor for glioblastoma. Cancer Genet Cytogenet, 172, 33-37.

Wu G, Hasenberg T, Magdeburg R, et al (2009). Association between EGF, TGF-beta1, VEGF gene polymorphism and colorectal cancer. World J Surg, 33, 124-9.

Ying Piao, Liu Z, Ding Z, et al (2013). EGF +61 A $>$ G polymorphism and gastrointestinal cancer risk: a HuGE review and meta-analysis. Gene, 519, 26-33.

Zhang YM, Cao C, Liang K (2010). Genetic polymorphism of epidermal growth factor $61 \mathrm{~A}>\mathrm{G}$ and cancer risk: a metaanalysis. Cancer Epidemiol, 34, 150-6. 